\title{
Role of Corporate Governance in the Financial Crisis; Evidence from Nigerian Banks
}

\author{
Oyewole Oyedayo Sharon, Olusanmi Olamide and Owolabi Folashade
}

\author{
Covenant University, Ota, Nigeria \\ Correspondence should be addressed to: Oyewole Oyedayo Sharon; \\ oyedayo.oyewole@covenantuniversity.edu.ng \\ Received date: 6 March 2014; Accepted date: 10 August 2014; Published date: 14 October 2015
}

Copyright (C) 2015. Oyewole Oyedayo Sharon, Olusanmi Olamide and Owolabi Folashade. Distributed under Creative Commons CC-BY 4.0

\begin{abstract}
Accessing problems from the perceived causes usually leads to a relief or solution. This paper examines corporate governance and the Nigerian financial crisis which was majorly characterised by poor credit risk management, with the aim to determine the relationship that exists between corporate governance and credit risk management. Secondary data were gathered from 19 listed Nigerian banks for a 5 year period between 2005 and 2009; the postconsolidation to financial sector crash in Nigeria. Corporate governance is measured by statutory committee, committee independence, board size, board composition, executive duality and directors' interest; while credit risk management is measured by non-performing loans ratio, loan loss provision, and loan to deposit ratio. The data were analysed by Ordinary least square panel data analysis. Findings revealed that banks with good corporate governance have better credit risk management. Results of the hypotheses tests revealed that there is a significant relationship between corporate governance and the credit risk management variables: non-performing loans ratio; loan loss provision; and loans to deposits ratio. This paper recommends that directors of banks should ensure compliance with corporate governance policies for a more thorough administration of the financial system.
\end{abstract}

Keywords: Corporate Governance; Financial Crisis; Credit Risk; Nigerian Banks

\section{Introduction}

Corporate governance is crucial to the integrity of corporations, financial institutions, and central to the health and stability of economies. Corporate governance is the set of processes, customs, policies, laws, and institutions affecting the way a corporation (or company) is directed, administered or controlled. Cherupalli (2011) explained that Sound corporate governance is reliant on external 
marketplace commitment and legislation, plus a healthy board culture which safeguards policies and processes as mentioned by. Every business endeavour involves risks that could present threats to its success, and management of such is crucial to the business. Risk is the chance that an investment's actual return will be different from the expected, that is; the quantifiable likelihood of loss or less-thanexpected returns. It includes the possibility of losing some or all of the original investment. Munger (2011) suggests that Risk should be measured, avoided if possible, and a margin of safety determined. Sloan (2011) mentioned that banking by nature of its operations is highly risky. Banks safeguard money and provide credit and render payment services such as checking accounts, debit cards, and cashier's checks. Banks may also offer investment and insurance products. Sobodu \& Akiode (1998) opined that through the financial intermediation function and the spread of bank branches, they were relied on to take result-oriented approach to export promotion, diversification and the revamping of industrial development and growth in Nigeria.

Discovery of the causes of an economic phenomenon is very crucial to the future prevention mechanisms and sustainability of the recovered system. The recent global financial crisis was caused by some phenomenal factors. In a research study by Ernst \& Young (2010), it was found that the financial crisis exposed inherent weakness in the risk management system; soiled infrastructures, disparate systems and processes, fragmented decision-making, inadequate forecasting and a dearth of cohesive reporting, among others. The Association of Certified Chartered Accountants (2008) mentioned that many of the causal factors that caused the financial crisis seem to be inextricably linked to a noncompliance with corporate governance policies.

\section{Nigerian Financial Sector Crisis}

The Nigerian banking sector is sensitive to the economic and financial wellbeing of the country. Soludu (2009) stated that the financial system is dominated by the banking sector (about $90 \%$ of the assets and about $65 \%$ of the market capitalization of the Nigerian Stock Exchange). It is the key driver of the economy with new credit to the private sector expected to exceed the combined spending by three tiers of government. In 2005, this sector experienced a major reform as banks were consolidated through mergers and acquisitions, raising the capital base from $\mathrm{N} 2$ billion to a minimum of N25 billion, which reduced the number of commercial banks from 89 to 25 and later to 24 and currently 16. Sanusi (2011) mentioned that beyond the need to recapitalize the banks, the reforms focused on ensuring minimal reliance on the public sector for funds, but rather relying on the private sector. In a research study by Ernst and Young (2010), it was found that as the focus on risk intensifies, organizations are enhancing their management of key risks, which include: credit risk as top of the agenda; operational risk, liquidity risk, market risk, and reputational risk.

Credit risk which is placed as a priority is explained by Chin (2010) as the possibility of loss due to a debtor's non-payment of a loan or other line of credit (either the principal, interest or both). The default events include a delay in repayments, restructuring of borrower repayments, bankruptcy of the firm and has negative consequences for the economy. Chike-obi (2011) revealed that over $\$ 770$ billion has been spent by the government on buying the bad loans of Nigerian banks.

In a research study by Barfield \& Venkat (2010), it was found that during the times of financial crisis, risks have repeatedly shown a tendency to transform from one type to another with breath-taking speed. We have seen, for example, how mistrust of asset values due to credit default risk can generate

Oyewole Oyedayo Sharon, Olusanmi Olamide and Owolabi Folashade (2015), Journal of Accounting and Auditing: Research \& Practice, DOI: 10.5171/2015.367443 
liquidity risk. So, going forward, banks will need to place greater emphasis on developing an integrated view of risk across all the risk types. Andre (2009) noted that most banking crises have had as direct causes, the inadequate management of credit risk and after East Asian economies collapsed in the late 20th century, the World Bank's president warned those countries, that for sustainable development, corporate governance has to be firm.

Banks in Nigeria were recapitalised in 2005 requiring, from each bank, a minimum capital base of 25 billion. With the huge amount of funds that are available to them, banks have been financing more long-term mega projects in the real sectors of the economy as opposed to the existing working capital/trade financing.

The financial crisis in the Nigerian Banking Sector can be specifically attributed to the huge loss suffered by most of the banks in the form of non-performing loans which suggests poor credit risk management. In a research study by Soludo (2009), it was discovered that 8 of the Nigerian banks had issued out loans without observing due process, also some loans were not serviced and no action was taken by the bank which resulted in N620billion loss for poor credit management. This draws attention to the effectiveness and efficiency of their credit risk management principles, which in turn questions their compliance with corporate governance policies.

\section{Corporate Governance}

In April 2003, the Code of Best Practices on Corporate Governance in Nigeria was published and the implementation process began immediately. O'Donovan (2006) defines corporate governance as 'an internal system encompassing policies, processes and people, which serves the needs of shareholders and other stakeholders, by directing and controlling management activities with good business savvy, objectivity, accountability and integrity.
Sound corporate governance is reliant on external marketplace commitment and legislation, plus a healthy board culture which safeguards policies and processes. Catherine and John (2002) explained corporate governance as a means whereby society can be sure that large corporations are well-run institutions to which investors and lenders can confidently commit their funds. It is now increasingly clear that having a transparent and fair system to govern markets, fair treatment of all stakeholders, and a chance for every entrepreneur with a good product to be successful, are important to democracy. Corporate governance creates safeguards against corruption and mismanagement, while promoting the fundamental values of a market economy in a democratic society. Vijaianand (2009) identified the key elements of corporate governance principles as follows: Honesty; Trust and integrity; Openness; Performance orientation; Responsibility and accountability; Mutual respect; and Commitment to the organization.

\section{The Central Bank of Nigeria's code of corporate governance for banks in Nigeria post consolidation}

The Central Bank of Nigeria (2006) stated guidelines for corporate governance which specifically address the governance of banks in Nigeria. These guidelines are referred to as code of corporate governance and they cover every recognised matter of governance in banks. This new code therefore was developed to compliment the earlier ones and enhance their effectiveness for the Nigerian banking industry. Compliance with the provisions of this code is mandatory. The policies of the code are stated as follows:

\section{Credit Risk Management}

Rose \& Hudgins (2005) define Credit risk as the probability that some of the bank's assets will decline in value and perhaps become worthless. Chin (2010) explains Credit risk as the possibility of loss due to a debtor's nonpayment of a loan or other line of credit 
(either the principal, interest or both). The default events include a delay in repayments, restructuring of borrower repayments, and bankruptcy. The Central Bank of Nigeria (2006) Code of Corporate Governance includes some credit risk management policies:

1. The Board Credit Committee should have neither the Chairman of the Board nor the Managing Director as its chairman.

2. The Board Credit Committee should be composed of members knowledgeable in credit analysis.

\section{Agency Theory}

The main issue in the principal/agency literature is centred on asymmetric information because outside owners do not have access to full information on corporate performance or the reasons for underperformance. Sadiq, Oyebola \& Abdulrasheed (2011) mentioned that the separation of ownership and control, which occurs as a result of the introduction of external investors, brings to the fore the agency problem: managers are expected to represent the interest of the external owners.

Kieiman (2011) explains Agency theory to suggest that the firm can be viewed as a nexus of contracts between resource holders. An agency relationship arises whenever the principals hire agents, to perform some services and then delegate decision-making authority to the agents. The primary agency relationships in business are those between stockholders and managers; and between debt holders and stockholders.

Eisenhardt (1989) mentioned that there is likely to be conflict between the interests of principals and agents. However, the management decisions of a bank should be in line with the Principal-agent relationships and should reflect efficient organization of information and risk-bearing costs.

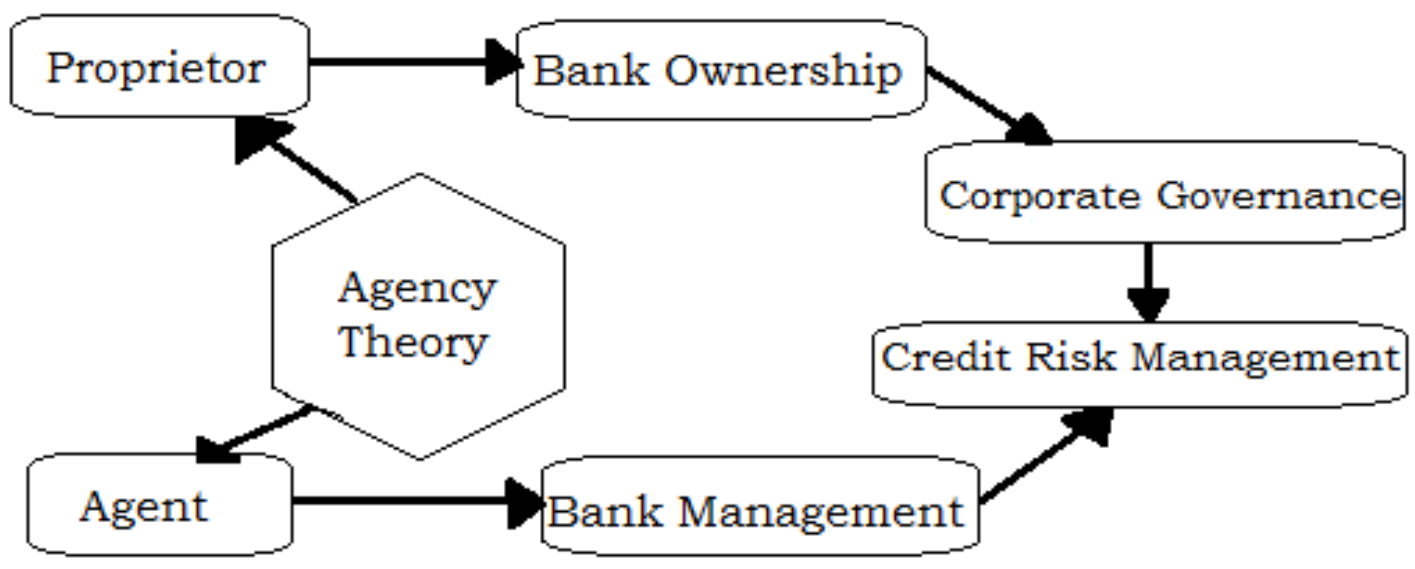

Figure 1: Agency Theory Framework

\section{Source: Developed By the Researcher}

This diagram represents the relationship between corporate governance and credit risk management on the platform of agency theory. Agency theory majorly backs up the contractual agreement between the proprietor and the agent. The agents have been identified as bank management and credit risk management is one of their major 
responsibilities. Bank owners have been identified as proprietors who have corporate governance as their major concern.

\section{Literature Review}

Awoyemi (2009) explains that there exists a huge incentive to foster the strategic development of 'cordial' relationships and back door channels with regulators to feed the private sector's desire for an edge in business. He identified this as a strong point for further research since the implementation of corporate governance largely depends on regulation. Ericsson \& Renault (2006) noted that a rapidly growing body of literature has focused on credit risk and this further stresses the importance of credit risk management. The Organization for Economic Co-operation and Development (2004) stated that one of the most influential guidelines has been the 1999 OECD Principles of Corporate Governance. This was revised in 2004. The OECD remains a proponent of corporate governance principles throughout the world.

In a research study by Eduardus, Hermeindito, Putu \& Supriyatna (2007) it was found that the relationships between corporate governance and credit risk management; and between corporate governance and bank performance are sensitive to the type of bank ownership. Foreign-owned banks have better implemented corporate governance than have joint venture- owned banks, stateowned banks, and private domestic-owned banks. Joan, Anthony \& Anthony (2009) emphasize the impact of the strength of the board of directors and constructed an indicator of board strength. They concluded that board strength does not have a significant impact on capital risk, credit risk nor liquidity risk in Ghanaian banks. Greuning and Bratanovic (2004) argued that each of the key players in the corporate governance process (such as shareholders, directors, executive managers, and internal and external auditors) is responsible for some component of financial and operational risk management. Verriest \& Gaeremynck (2008) hypothesized that in a changing accounting environment; better governed firms will provide a better financial restatement quality. The results largely confirm this prediction.

\section{Methodology}

Fox (2002) states a general regression model as: $y_{i t}=\alpha+\beta^{\prime} X_{i t}+u_{i t}$.

Takang \& Ntui (2008) in analysing the relationship between bank performance and credit risk management stated their model as:

$\mathrm{P}(\mathrm{ROA}, \mathrm{ROE})=\alpha+\beta \mathrm{NPL} / \mathrm{TL}+\mu$

Joan et. al., (2009) examined the impact of corporate governance of Ghanaian banks on the management of bank capital risk, credit risk, and liquidity risk. The relationship is hypothesized as:

Yjit=Ajit Xkit+ $\epsilon$ jit

Verriest \& Gaeremynck (2008) examined the impact of corporate governance on IFRS and modelled the relationship as follows:

QRIFRS

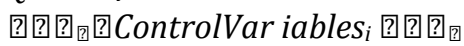

The regression model for this study was therefore adapted from the 4 models stated above:

CR (NPL, LLP, LDR) $i t=\alpha+\beta \mathrm{SC}_{i t}+\beta \mathrm{CI}_{i t}+\beta \mathrm{BS}_{i t}$ $+\beta \mathrm{BC}_{i t}+\beta \mathrm{ED}_{i t}+\beta \mathrm{DI}_{i t}+\beta \mathrm{TA}_{i t}+\mu_{i t}$

Where:

$\mathrm{CR}$ is the dependent variable, the variable we wish to explain or predict which is credit risk management (NPL, LLP, LDR).

CG is the independent variable, also called the predictor variable; which is, corporate governance (SC, CI, BS, BC, ED, DI,).

$\boldsymbol{\alpha}$ is the intercept and

$\boldsymbol{\beta}$ is the parameter of explanatory variable

Oyewole Oyedayo Sharon, Olusanmi Olamide and Owolabi Folashade (2015), Journal of Accounting and Auditing: Research \& Practice, DOI: 10.5171/2015.367443 
$\boldsymbol{\mu}$ represents the disturbance terms.

$\boldsymbol{i}$ represent all the 19 banks in the sample; and

$\boldsymbol{t}$ the 5 time period.

Thus, three equations are implied in equation (1), one each for non - performing loans ratio, loan loss provision and loans to deposits ratio. The explanatory variables are repeated for the dependent variable.

$\mathrm{CR}(\mathrm{NPL})_{i t}=\alpha+\beta \mathrm{SC}_{i t}+\beta \mathrm{CI}_{i t}+\beta \mathrm{BS}_{i t}+\beta \mathrm{BC}_{i t}+$ $\beta \mathrm{ED}_{i t}+\beta \mathrm{DI}_{i t}+\beta \mathrm{TA}_{i t}+\mu_{i t}-\cdot-\cdot-\cdot-\cdot-\cdot---(1)$

$\mathrm{CR}(\mathrm{LLP})_{i t}=\alpha+\beta \mathrm{SC}_{i t}+\beta \mathrm{CI}_{i t}+\beta \mathrm{BS}_{i t}+\beta \mathrm{BC}_{i t}+$ $\beta \mathrm{ED}_{i t}+\beta \mathrm{DI}_{i t}+\beta \mathrm{TA}_{i t}+\mu_{i t}$

$\mathrm{CR}(\mathrm{LDR})_{i t}=\alpha+\beta \mathrm{SC}_{i t}+\beta \mathrm{CI}_{i t}+\beta \mathrm{BS}_{i t}+\beta \mathrm{BC}_{i t}+$ $\beta \mathrm{ED}_{i t}+\beta \mathrm{DI}_{i t}+\beta \mathrm{TA}_{i t}+\mu_{i t}$

Each of the equations is applied for the relevant hypothesis test 1,2 and 3 respectively.

Ordinary Least Square analysis was carried out on the panel data using Eviews 7.

\section{Credit Risk Management Variables}

\section{Non-Performing Loans Ratio (NPL)}

Chang (2006) stated that loan is represented by total loans and advances in notes to the financial statement. Banks have realised that revenue maximising does not protect them from losses due to non-performing loans. The values for Non-performing loans are extracted from the analysis of loans and advances by performance. The formula for deriving the ratio is expressed below:

$$
\text { NPL }=\underline{\text { Non-performing Loans }}
$$$$
\text { Total Loans }
$$

\section{Loan Loss Provision (LLP)}

Chang (2006) mentioned that it is important for each bank to have a proportion of the total loans in non - performing loans, on which the bank has to build provisions. This estimates what percentage of the total loans has been provided for. The formula for deriving the ratio is expressed below:

\section{LLP $=\underline{\text { Provision for Loan Losses }}$ Total Loans}

In a study by Joan et. al. (2009), it was found that the higher this provision becomes, relative to the size of total loans, the riskier a bank becomes. Credit risk, defined as the ratio of loan loss provision to total loans. This ratio is commonly used in literature. Eduardus et. al. (2007) explained that a high ratio is considered as an indicator of poor credit risk management. Loan is represented by total loan in the balance sheet.

The Central Bank of Nigeria requires all banks to make provisions for their loans according to the loan classification: Performing loans (past due $<1$ day-89days) to be set at 1\%; Standard loans (past due $>90$ days-179days) to be set at $10 \%$; Doubtful loans (past due $>180$ days-359days) to be set at 50\%; Lost loans (past due (>360days) to be set at $100 \%$ (CBN Prudential Guideline, 2010).

\section{Loans to deposits ratio (LDR)}

Loans are represented by total loans and advances in notes to the financial statement, whilst the deposits include demand deposits, time deposits, fixed deposits, current deposits, and savings. The total deposits value is extracted from the liabilities section of the balance sheet, referred to as customer deposits. Eduardus et. al (2007) noted that this ratio shows the proportion of public contribution as a source of capital to finance the banks' loans. Smaller LDR number indicates that public provides smaller proportion to support the banks' loans. The formula for deriving the ratio is expressed below:

$$
\text { LDR }=\frac{\text { Total Loans }}{\text { Total Deposits }}
$$




\section{Corporate Governance Variables}

\section{Statutory Committee (SC)}

The Central Bank of Nigeria by the code of corporate governance 2006 requires each of the banks in Nigeria to have at least the following 3 committees: audit committee; credit committee; and risk committee. Therefore, data were gathered on the existence of these committees in each of the observations, checking whether the bank had none that is, 0 ; all $3 ; 1$ or 2 of these committees.

\section{Committee Independence (CI)}

The Central Bank also requires that neither the chairman of the board nor the managing director/chief executive officer should be a member or chairman of any of the existing committees. This is to ensure independence of these committees of the board of directors. The committees of observations that had either the chairman or the managing director/chief executive officer as a member or chairman were regarded as dependent and represented by dummy value ' 0 '; while the committees of observations that had neither the chairman of the board or the managing director/chief executive officer as a member or chairman are regarded as independent and represented by dummy value ' 1 '.

\section{Board Size (BS)}

It is also required by the Central Bank that the board of directors of any bank in Nigeria does not exceed a total of 20 directors. Data were practically gathered by counting the number of directors listed as members of the board. The total membership of the board of directors includes: The chairman, the managing director/chief executive director, executive directors and non-executive directors.

\section{Board Composition (BC)}

It is required by the 2006 Central Bank of Nigeria code of corporate governance that the board of directors comprises of the chairman, the managing director/chief executive director, executive directors and non-executive directors. The chairman of the board is a non-executive director, while the managing director/ chief executive officer is an executive director. It is further stated that the number of non-executive directors should exceed that of executive directors. Hence, in gathering data, where the executive directors exceeded the nonexecutive directors or are the same number, it was represented by dummy value ' 0 ' and where the non-executive directors exceeded the executive directors, it was represented by dummy value ' 1 '.

\section{Executive Duality (ED)}

The Central Bank of Nigeria, in the 2006 code of corporate governance also requires that the position of chairman of the board of directors and managing director/chief executive officer should not be vested in one person or two relates persons. Therefore in gathering data, the observations that had one person or two related parties as chairman of the board and managing director/chief executive officer were valued by dummy ' 0 '. While, the observations that had two unrelated persons as chairman of the board and managing director/chief executive officer were valued by dummy ' 1 '.

\section{Directors' Interest (DI)}

Though not mandated, it is clearly noted in the 2006 Central Bank of Nigeria code of corporate governance that the more the directors' shareholding interest in the bank, the better the with corporate governance principles. Hence, it was further stated that the directors are advised to acquire shares in the banks they are directing. In data gathering, the total shareholding of all the directors was summed and expressed as a percentage of total shares of the bank.

Oyewole Oyedayo Sharon, Olusanmi Olamide and Owolabi Folashade (2015), Journal of Accounting and Auditing: Research \& Practice, DOI: 10.5171/2015.367443 


\section{Control Variable}

For this research, bank size was considered a relevant control variable and it was measured by banks' total assets (TA).

\section{Results}

\section{Table 1: Group correlation of variables}

\begin{tabular}{|c|c|c|c|c|c|c|c|c|c|c|}
\hline & $B C$ & BS & $\mathrm{Cl}$ & DI & ED & SC & TA & NPL & LLP & LDR \\
\hline BC & 1 & & & & & & & & & \\
\hline BS & 0.123205 & 1 & & & & & & & & \\
\hline $\mathrm{Cl}$ & 0.118107 & 0.279182 & 1 & & & & & & & \\
\hline DI & 0.004707 & -0.2577 & -0.25287 & 1 & & & & & & \\
\hline ED & -0.04744 & 0.088634 & 0.151354 & -0.04262 & 1 & & & & & \\
\hline SC & 0.021106 & 0.329219 & 0.785224 & -0.36977 & -0.05535 & 1 & & & & \\
\hline TA & -0.12685 & 0.61659 & 0.359881 & -0.20628 & 0.064152 & 0.410902 & 1 & & & \\
\hline NPL & 0.090744 & -0.13406 & 0.08398 & -0.14757 & 0.099337 & 0.140488 & -0.21567 & 1 & & \\
\hline LLP & 0.120809 & -0.18278 & 0.003643 & -0.20912 & 0.140526 & -0.00182 & -0.26343 & 0.551591 & 1 & \\
\hline LDR & -0.2161 & -0.21089 & 0.02939 & 0.000911 & 0.080289 & 0.100126 & -0.20699 & -0.00198 & -0.12392 & 1 \\
\hline
\end{tabular}

O'Brien (2007) explained multicollinearity as a statistical phenomenon in which two or more predictor variables in a multiple regression model are highly correlated. The result of the multicollinearity shows that the relationship between each of the variable sets is negative and at some point positive but insignificant.
$\mathbf{H}_{\mathbf{0}}$ 1: There is no significant relationship between corporate governance and nonperforming

Loans ratio.

$\mathrm{CR}(\mathrm{NPL})_{i t}=\alpha+\beta \mathrm{SC}_{i t}+\beta \mathrm{CI}_{i t}+\beta \mathrm{BS}_{i t}+\beta \mathrm{BC}_{i t}+$ $\beta \mathrm{ED}_{i t}+\beta \mathrm{DI}_{i t}+\beta \mathrm{TA}_{i t}+\mu_{i t}$

\section{Test of Hypothesis 1}

Table 2: Regression output for Hypothesis 1

\begin{tabular}{|l|l|r|r|r|}
\hline $\begin{array}{l}\text { Dependent Variable: NPL } \\
\text { Method: Panel Least Squares }\end{array}$ & \\
\hline Sample: 20052009 & & & \\
\hline Periods included: 5 & & & \\
\hline Cross-sections included: 19 & & \\
\hline Total panel (balanced) observations: 95 & & \\
\hline Variable & Coefficient & Std. Error & t-Statistic & Prob. \\
\hline BC & 0.059467 & 0.074643 & 0.796691 & 0.4278 \\
\hline BS & -0.006384 & 0.00848 & -0.752897 & 0.4535 \\
\hline Cl & -0.053531 & 0.071438 & -0.749332 & 0.4557 \\
\hline DI & -0.464803 & 0.393829 & -1.180216 & 0.2411 \\
\hline ED & 0.23561 & 0.1525 & 1.544984 & 0.126 \\
\hline SC & 0.082197 & 0.042319 & 1.942296 & 0.0553 \\
\hline TA & $-1.36 E-07$ & $6.67 E-08$ & -2.036882 & 0.0447 \\
\hline C & -0.076548 & 0.208409 & -0.367298 & 0.7143 \\
\hline R-squared & 0.153958 & Mean dependent var & 0.187231 \\
\hline Adjusted R-squared & 0.085886 & S.D. dependent var & 0.208153 \\
\hline S.E. of regression & 0.199014 & Akaike info criterion & -0.310431 \\
\hline Sum squared resid & 3.445773 & Schwarz criterion & -0.095367 \\
\hline Log likelihood & 22.74545 & Hannan-Quinn criter. & -0.223529 \\
\hline F-statistic & 2.261684 & Durbin-Watson stat & 1.442162 \\
\hline Prob(F-statistic) & 0.036595 & & \\
\hline
\end{tabular}

Oyewole Oyedayo Sharon, Olusanmi Olamide and Owolabi Folashade (2015), Journal of Accounting and Auditing: Research \& Practice, DOI: 10.5171/2015.367443 
The coefficients of BS, CI, DI and TA show that there is an inverse relationship with non-performing loans ratio. This implies that as the number of directors on the board increases, the ratio of non-performing loans to total loans will fall and vice versa. The independence of the board committees influences a reduction in non-performing loans ratio and vice versa. As shareholding interests of the directors increase, ratio of non-performing loans to total loans falls and vice versa; also as bank total assets increase, non-performing loans ratio falls and vice versa. BC, ED and SC show a positive relationship. As the number of non-executive directors increases in greater proportion to the executive directors, non-performing loans ratio increases and vice versa. Clear separation of powers between the chairman board of directors and the CEO influences an increase in non-performing loans ratio. Compliance with the statutory committees increases the ratio of non-performing loans to total loans.
The 0.036595 Prob (F-statistic) is significant at $5 \%$, and this represents $95 \%$ level of significance. Therefore, the null hypothesis that there is no significant relationship between corporate governance and nonperforming loans ratio is rejected. Therefore, it is concluded that there is a significant relationship between corporate governance and non-performing loans ratio. The regression result proves that as corporate governance policies are complied with, there is a significant impact on non-performing loans ratio. The R-squared proves that corporate governance is responsible for $15.4 \%$ change in non-performing loans ratio.

\section{Test of Hypothesis 2}

$\mathbf{H}_{\mathbf{0}}$ 2: There is no significant relationship between corporate governance and loan loss Provision. $\mathrm{CR}(\mathrm{LLP})_{i t}=\alpha+\beta \mathrm{SC}_{i t}+\beta \mathrm{CI}_{i t}+\beta \mathrm{BS}_{i t}+$ $\beta \mathrm{BC}_{i t}+\beta \mathrm{ED}_{i t}+\beta \mathrm{DI}_{i t}+\beta \mathrm{TA}_{i t}+\mu_{i t}$

Oyewole Oyedayo Sharon, Olusanmi Olamide and Owolabi Folashade (2015), Journal of Accounting and Auditing: Research \& Practice, DOI: $10.5171 / 2015.367443$ 
Table3: Regression Output for Hypothesis 2

\begin{tabular}{|l|r|r|r|r|}
\hline $\begin{array}{l}\text { Dependent Variable: LLP } \\
\text { Method: Panel Least Squares }\end{array}$ & & \\
\hline Sample: 2005 2009 & & & \\
\hline Periods included: 5 & & & \\
\hline Cross-sections included: 19 & & & \\
\hline Total panel (balanced) observations: 95 & & \\
\hline Variable & Coefficient & Std. Error & t-Statistic & Prob. \\
\hline BC & 0.530591 & 0.449667 & 1.179965 & 0.2412 \\
\hline BS & -0.059084 & 0.051083 & -1.156617 & 0.2506 \\
\hline Cl & -0.129804 & 0.43036 & -0.301618 & 0.7637 \\
\hline DI & -6.012821 & 2.372518 & -2.534362 & 0.0131 \\
\hline ED & 1.5665 & 0.918696 & 1.705135 & 0.0917 \\
\hline SC & 0.138111 & 0.254942 & 0.541735 & 0.5894 \\
\hline TA & $-7.32 E-07$ & $4.02 E-07$ & -1.821557 & 0.072 \\
\hline C & -3.268773 & 1.255508 & -2.603546 & 0.0108 \\
\hline R-squared & 0.186833 & Mean dependent var & -2.430938 \\
\hline Adjusted R-squared & 0.121406 & S.D. dependent var & 1.279062 \\
\hline S.E. of regression & 1.198908 & Akaike info criterion & 3.281152 \\
\hline Sum squared resid & 125.0521 & Schwarz criterion & 3.496215 \\
\hline Log likelihood & -147.8547 & Hannan-Quinn criter. & 3.368053 \\
\hline F-statistic & 2.855581 & Durbin-Watson stat & 0.95222 \\
\hline Prob(F-statistic) & 0.009918 & & & \\
\hline
\end{tabular}

The coefficients of BS, CI, DI and TA show that there is an inverse relationship with LLP ratio. This implies that as the number of directors on the board increases, the ratio of LLP falls and vice versa. The independence of the board committees influences a reduction in LLP ratio and vice versa. The larger the shareholding interests of the directors, ratio of LLP falls and vice versa; also as bank total assets increase, provision for loan losses falls and vice versa. $\mathrm{BC}, \mathrm{ED}$ and SC indicate a positive relationship. As the number of nonexecutive directors increases in greater proportion to the executive directors, LLP increases and vice versa. Clear separation of powers between the chairman board of directors and CEO influences an increase in LLP. Compliance with statutory committees results in higher LLP ratio.

The 0.009918 Prob(F-statistic) is significant at $1 \%$ and this represents $99 \%$ level of significance. Therefore, the null hypothesis that there is no significant relationship between corporate governance and loan loss provision is rejected. Therefore, it is concluded that there is a significant relationship between corporate governance and loan loss provision. The regression result proves that as corporate governance compliance improves, there is a significant impact on provision for loan losses and vice versa. The R-squared proves that corporate governance is responsible for $18.7 \%$ change in loan loss provision.

\section{Test of Hypothesis 3}

$\mathrm{H}_{0}$ 3: There is no significant relationship between corporate governance and loans to deposits

ratio.

$\mathrm{CR}(\mathrm{LDR})_{i t}=\alpha+\beta \mathrm{SC}_{i t}+\beta \mathrm{CI}_{i t}+\beta \mathrm{BS}_{i t}+$

$\beta \mathrm{BC}_{i t}+\beta \mathrm{ED}_{i t}+\beta \mathrm{DI}_{i t}+\beta \mathrm{TA}_{i t}+\mu_{i t}$ 
Table 4: Regression Output for Hypothesis 3

\begin{tabular}{|c|c|c|c|c|}
\hline \multicolumn{5}{|c|}{ Dependent Variable: LDR } \\
\hline \multicolumn{5}{|c|}{ Method: Panel Least Squares } \\
\hline \multicolumn{5}{|l|}{ Sample: 20052009} \\
\hline \multicolumn{5}{|l|}{ Periods included: 5} \\
\hline \multicolumn{5}{|c|}{ Cross-sections included: 19} \\
\hline \multicolumn{5}{|c|}{ Total panel (balanced) observations: 95} \\
\hline Variable & Coefficient & Std. Error & t-Statistic & Prob. \\
\hline BC & -0.292435 & 0.133183 & -2.195747 & 0.0308 \\
\hline BS & -0.011362 & 0.01513 & -0.750991 & 0.4547 \\
\hline $\mathrm{Cl}$ & -0.078529 & 0.127464 & -0.616087 & 0.5394 \\
\hline DI & 0.184469 & 0.702694 & 0.262517 & 0.7935 \\
\hline ED & 0.346794 & 0.2721 & 1.274508 & 0.2059 \\
\hline SC & 0.151086 & 0.075509 & 2.000905 & 0.0485 \\
\hline TA & $-2.53 E-07$ & 1.19E-07 & -2.128557 & 0.0361 \\
\hline C & 0.517765 & 0.371857 & 1.392376 & 0.1674 \\
\hline R-squared & 0.172743 & \multicolumn{2}{|c|}{ Mean dependent vaı } & 0.613418 \\
\hline Adjusted R-squared & 0.106183 & \multicolumn{2}{|c|}{ S.D. dependent var } & 0.375594 \\
\hline S.E. of regression & 0.355093 & \multicolumn{2}{|c|}{ Akaike info criterion } & 0.847581 \\
\hline Sum squared resid & 10.96995 & \multicolumn{2}{|c|}{ Schwarz criterion } & 1.062644 \\
\hline Log likelihood & -32.26008 & \multicolumn{2}{|c|}{ Hannan-Quinn criter } & 0.934482 \\
\hline F-statistic & 2.595271 & \multicolumn{2}{|c|}{ Durbin-Watson stat } & 1.548389 \\
\hline Prob(F-statistic) & 0.017647 & & & \\
\hline
\end{tabular}

The coefficients of $\mathrm{BC}, \mathrm{BS}, \mathrm{CI}$ and $\mathrm{TA}$ show that there is an inverse relationship with LDR. This implies that as the number of nonexecutive directors increases in greater proportion to the executive directors, LDR decreases and vice versa. As the number of directors increases, LDR falls and vice versa. The independence of the board committees influences a reduction in LDR and vice versa; also as bank total assets increase, LDR falls and vice versa. DI, ED and SC show a positive relationship. As directors' shareholding interests increase, LDR falls and vice versa. Clear separation of powers between the chairman board of directors and CEO influences an increase in LDR. Compliance with results in higher LDR.

The 0.017647 Prob (F-statistic) is significant at $5 \%$, and this represents $95 \%$ level of significance. Therefore, the null hypothesis that there is no significant relationship between corporate governance and loans to deposits ratio is rejected. Therefore, it is concluded that there is a significant relationship between corporate governance and loans to deposits ratio. The regression result proves that as corporate governance compliance improves, there is a significant impact on loans to deposits ratio. The Rsquared proves that corporate governance is responsible for $17.3 \%$ change in loans to deposits ratio.

\section{Conclusion}

This work aimed at determining the relationship that exists between corporate governance and credit risk management in Nigerian Banks focusing on the financial crisis. A model was designed to explain the relationship between corporate governance and credit risk management, hinging on the agency theory. Secondary data were gathered from 19 listed Nigerian banks for a 5 year period between 2005 and 2009. Corporate governance was measured by statutory committee, committee independence, board size, board composition, executive duality and directors' interest; while credit risk management was measured by non- 
performing loans ratio, loan loss provision, and loan to deposit ratio. The data were analysed by Ordinary least square panel data analysis. Findings revealed that banks with sound corporate governance practice have better credit risk management. Results of the hypotheses tests revealed that there is a significant relationship between corporate governance and credit risk variables: NPL; LLP and LDR. These imply that an improvement in corporate governance practice would result in more efficient management of credit risk, hence reduce the risk of a financial crisis reoccurrence. In a research study by Eduardus et. al. (2007), Indonesian banks incorporate significant relationship between corporate governance and risk management. This supports the findings stated above for credit risk management in Nigerian banks.

This study was carried out on only commercial banks, excluding other financial institutions in the country and focus was only on credit risk. Further research can be carried out on other financial institutions or micro-finance banks in Nigeria. Also, other risks can be focused on such as; liquidity risk, operational risk, market risk, and reputational risk.

\section{References}

1. Andre, J. B. (2009), "Dynamic provisioning and IFRS adoption by Nigerian banks; The procyclical nature of the current international loan loss provisioning regime". [Online], [Retrieved June 28, 2011], www.ubagroup.com/IFRS adoption by Nigerian banks.pdf

2. Association of Chartered Certified Accountants (2008), "Corporate governance and the credit

3. Crunch". [Online], [Retrieved January 20, 2011],
http://www.accaglobal/03IRMCorp orategovernanceandthecreditcrunch .pdf

4. Awoyemi, 0. (2009), "Corporate governance-Financial crisis and the Nigerian leadership melt down ". [Online], [Retrieved January 20, 2011],http://www.proshareng.com/ admin/upload/reports/Corporate\% 20Governance $\% 20$ in $\% 20$ Nigeria $\% 2$ 0\%20Proshare\%20290909\%20b.pd $\mathrm{f}$

5. Barfield, R. \& Venkat, S. (2010), 'Liquidity risk management', The Journal; Global Perspectives on Challenges and Opportunities, 10-15.

6. Central Bank of Nigeria (2006)," Code of Corporate Governance for banks in Nigeria postConsolidation". [Online], [Retrieved June 28, 2011],

7. www.cenbank.org/out/Publications /.../2006/corp.Govpost\%20con.pdf

8. Central Bank of Nigeria (2010), "Prudential Guidelines for Deposit Money Banks in Nigeria". [Online],

9. [Retrieved June 28, 2011], www.nigeriamicrofinance.org/2011 /.../prudential-guidelines-for-de... -

10. Chang, Y. T. (2006), "The role of non-performing loans (NPLs) and capital adequacy in banking structure and competition". [Online], [Retrieved January 20, 2011],

11. www.unescap.org/stat/meet/snaapril2005/sna_nonperforming_loans.pdf

12. Cherupalli, K. (2011), "Corporate Governance". [Online], [Retrieved June 28, 2011], www.brasiladmin.com/index.php?... corporate-governance... 
13. Chike-obi (2011), "We have spent over N770bn to buy bank's bad loans". [Online], [Retrieved July 1, 2011], nigerianewsdaily.com > Business -

14. Chin, K. (2010), "How to Segment SME customer based on their risk profile". [Online], [Retrieved January 20, 2011], www.linkedin.com/answers/finance .../risk.../FIN.../674247-32862234

15. Eduardus, T., Hermeindito, K., Putu, A. \& Supriyanta (2007), Corporate Governance, Risk

Management, and Bank Performance: Does Type of Ownership Matter? ". [Online], [Retrieved January 20, 2011], www.eadn.org/eduardus.pdf

16. Eisenhardt, K. (1989), "Agency Theory: An Assessment \& Review", The Academy of

Management Review, 14, 57-74.

17. Ernst and Young (2010), "Three ways banks are rethinking risk strategies". [Online], [Retrieved July 1 ,

2011],http://ey.mobi/GL/en/Indust ries/Financial-Services/Banking--Capital-

Markets/2010_Global_risk_managm ent_survey_rethinking_risk_strategie s.

18. Ernst \& Young (2010), "Three ways global banks are strengthening risk governance process". [Online], [Retrieved July 1, 2011], http://www.Three\%20ways\%20glo bal\%20banks\%20are\%20strengthe ning $\% 20$ risk $\% 2$

0governance $\% 20$ processes $\% 20$ $\% 20$ Ernst $\% 20 \& \% 20$ Young $\% 20$ $\% 20$ Global.htm
19. Ericsson, J. \& Renault, 0. (2006), 'Liquidity and Credit risk', Journal of Finance, 61(5), 2219-2250.

20. Fox, J. (2002), "Time series regression and generalised leastsquares". [Online], [Retrieved June 28, 2011], appendit-timeseriesregression.pdf-wp_16975

21. Greuning, H. V. \& Bratanovic, S. B. (2004), "Analyzing and Managing Banking Risk: A

framework for assessing corporate governance and Financial Risk". [Online], [Retrieved June 28, 2011],

22. ebookee.org/Analyzing-andManaging-Banking-Risk-AFramework-for-AssessingCorporate-Governance-andFinancial-Risk_333269.html

23. Kieiman. R. (2011), "Agency Theory; Encyclopedia of Business". [Online], [Retrieved January 20, 2011], www.enotes.com , Business , Encyclopedia of Business beginnersinvest.about.com/.../retur n-on-assets-roa-incomestatement.htm

24. O'Brien, R. M. (2007), 'A Caution Regarding Rules of Thumb for Variance Inflation Factors. Quality and Quantity, 41(5), 673-690.

25. O'Donovan, G. (2006), “ Management and leadership: Guru interview ". [Online], [Retrieved July 1, 2011], first.emeraldinsight.com/interviews /pdf/odonovan.pdf

26. Organization for Economic Cooperation and Development (2004), "Organization for

Economic Co-operation and Development; Principles of corporate governance", [Online], [Retrieved July 1, 2011],

Oyewole Oyedayo Sharon, Olusanmi Olamide and Owolabi Folashade (2015), Journal of Accounting and Auditing: Research \& Practice, DOI: $10.5171 / 2015.367443$ 
http://www.oecd.org/document/49 $/ 0,3746$,en_2649_34795_31530865_ 1_1_1_1,00.html

27. Rose, C. S. and Hudgins, S. C (2005), "Bank Management and Financial Services". [Online], [Retrieved July 1, 2011], info.cba.ksu.edu/higgins/Finan531/ Bank\%20Performance\%20Measures .ppt

28. Sadiq, K., Oyebola, E., Abdulrasheed, A. (2011), "Agency problem in corporate governance in the Nigerian banking industry". [Online], [Retrieved January 20, 2011], http://www.unilorin.edu.ng/publica tions/rashraheem/Agency\%20Probl em\%20in\%20corporate\%20Govern ance $\% 20$ in $\% 20$ the $\% 20$ Nigerian $\% 2$ 0Banki.pdf

29. Sanusi, L. S. (2011), "Banks in Nigeria and National Economic Development: A criticalReview ". [Online], [Retrieved January 20, 2011],

http://www.cenbank.org/out/speec hes/2011/gov_banks\%20in\%20nige ria $\% 20$ and $\% 20$ national $\% 20$ econom ic\%20development_chc-cibnrbc_040611.pdf

30. Sloan, C. C. (2011), "Banking: Industry Profiles". [Online], [Retrieved July 1, 2011], www.careercornerstone.org/industr ies/banking.htm

31. Soludo, C. (2009), "Banking in Nigeria at a time of global financial crisis". [Online], [Retrieved June 28, 2011],www.cenbank.org/out/speec hes/2009/govadd30-3-09.pdf

32. Sobodu, O. \& Akiode, O. (1998), 'Bank performance and Supervision in Nigeria: Analysing

the transition to a deregulated economy', African Economic Research Consortium, 71 (1).

33. Takang, F. \& Ntui, C. (2008), "Bank Performance and Credit Risk Management". [Online], [Retrieved January 20, 2011], his.divaportal.org/smash/get/diva2:2459/F ULLTEXT01

34. Verriest, A. \& Gaeremynck, A. (2008), "Impact of corporate governance on IFRS restatement quality". [Online], [Retrieved June 28, 2011], aaahq.org/meetings/AUD2009/TheI mpactOfGovernance.pdf

35. Vijaianand (2009), "Corporate governance". [Online], [Retrieved January 20, 2011],http://www.indianmba.com/ Faculty_Column/FC1014/fc1014.ht $\mathrm{ml}$ 